Bangladesh J. Plant Taxon. 26(1): 13-28, 2019 (June)

(C) 2019 Bangladesh Association of Plant Taxonomists

\title{
FOUR NEW VARIETIES OF THE FAMILY ARACEAE FROM BANGLADESH
}

\author{
Hosene Ara $^{1}$ and Md. Abul Hassan ${ }^{2}$ \\ Bangladesh National Herbarium, Chiriakhana Road, Mirpur-1 \\ Dhaka-1216, Bangladesh
}

Keywords: New varieties; Araceae; Bangladesh.

\begin{abstract}
Four new varieties belonging to four species and three genera of the family Araceae are being described and illustrated from Bangladesh. The new varieties are: Colocasia fallax Schott var. purpurea H. Ara \& M.A. Hassan, Colocasia oresbia A. Hay var. stolonifera $\mathrm{H}$. Ara \& M.A. Hassan, Rhaphidophora calophyllum Schott var. violaceus $\mathrm{H}$. Ara \& M.A. Hassan and Typhonium trilobatum (L.) Schott var. fulvus H. Ara \& M.A. Hassan. The morphological diagnostic characters of each new variety and comparison with its closest one are provided. Detailed taxonomic description along with other relevant information are provided for easy recognition of the new aroid taxa.
\end{abstract}

\section{Introduction}

The family Araceae de Juss. is represented by 3,645 species globally under 144 genera (Boyce and Croat, 2011). In Bangladesh, the family consists of 27 genera and 109 species of which 81 species are wild and 29 are cultivated (Ara, 2016).

For revisionary work on the monocot family Araceae of Bangladesh the first author has made an extensive field survey throughout the country since 1988 and collected a good number of specimens. While examining the specimens, we came across some characteristically interesting unidentified specimens closest to Colocasia fallax Schott, C. oresbia A. Hay and Typhonium trilobatum (L.) Schott which were collected from different forests and homestead areas of Bangladesh. Moreover, some specimens of Rhaphidophora Hassk. collected from different forest areas of Moulvibazar district were found to be closest to R. calophyllum Schott. But differs from a number of characters. The flowering and fruiting samples of these specimens were preserved for identification in Bangladesh National Herbarium (DACB), Dhaka. The rhizomes of these specimens were also grown in the garden of Bangladesh National Herbarium (BNH), Dhaka; First author's rooftop garden at Khilgaon, Dhaka and in the Botanical Garden of the University of Dhaka. These interesting specimens were later critically examined and compared with the identified specimens of Colocasia fallax Schott, C. oresbia A. Hay, Rhaphidophora calophyllum Schott and Typhonium trilobatum (L.) Schott available at BK, BKF, BM, CAL, DACB, K, DUSH (Dhaka University Salar Khan Herbarium), HCU (Herbarium of Chittagong University), BCSIRH (Herbarium, Bangladesh Council for Scientific and Industrial Research) and BFRIH (Herbarium, Bangladesh Forest Research Institute). Besides, consultation of relevant literature (Wallich, 18291849; Roxburgh, 1832; Wight, 1843-1845; Hooker, 1893; Jackson, 1893-1955; Prain, 1903; Engler and Krause 1908, 1920; Engler, 1920; Heinig, 1925; Hu, 1968; Rao and Verma, 1976; Nicolson, 1976, 1979, 1987; Nasir, 1978; Nicolson and Sivadasan, 1981; Mayo, 1985; Karthikeyan et al., 1989; Hay, 1993, 1996; Noltie, 1994; Sriboonma et al., 1994; Sookchaloem, 1995; Liu and Huang, 1996; Mayo et al., 1997; Toha, 2000; Hetterscheid and Boyce, 2000; Wang et al., 2002; Warasy and Alam 2009; Heng et al., 2010) on the family Araceae were made. The

\footnotetext{
${ }^{1}$ Corresponding author, Email: bnh_mirpur@yahoo.com

${ }^{2}$ Department of Botany, University of Dhaka, Dhaka-1000, Bangladesh
} 
study revealed that these specimens were closest but sufficiently differed from other described varieties of the species Colocasia fallax Schott, C. oresbia A. Hay, Rhaphidophora calophyllum Schott and Typhonium trilobatum (L.) Schott and hence recognized as new varieties, Colocasia fallax Schott var. purpurea, Colocasia oresbia A. Hay var. stolonifera, Rhaphidophora calophyllum Schott var. violaceus and Typhonium trilobatum (L.) Schott var. fulvus respectively. These new varieties are described and illustrated below and compared in Tables 1-4.

\section{Results and Discussion}

1. Colocasia fallax Schott var. purpurea H. Ara \& M.A. Hassan, var. nov.

(Figs. $1 \& 2$ ).

Diagnosis: Colocasia fallax Schott var. purpurea H. Ara \& M.A. Hassan is very closely related to Colocasia fallax Schott var. fallax but can be easily differentiated by the green colour petiole and peduncle with purple to light purple admixture; sterile male zone more than $1 \mathrm{~cm}$ long; and chromosome number, $2 \mathrm{n}=30$.

Holotype: Bangladesh, Moulvibazar district, Madhabkundo reserve forest, 20.05. 2005, Hosne Ara HA 1709 (DACB).

Bengali name: Ban kachu.

A herb, 30-68 cm high, rhizome c. $1.5 \mathrm{~cm}$ in diameter, freely rooting at the nodes. Stolon c. $39 \mathrm{~cm}$ long, c. $0.5 \mathrm{~cm}$ in diameter. Leaf blade $10-25 \times 8-23 \mathrm{~cm}$, narrowly oblong-ovate, apiculate, base rounded with a shallow rounded sinus, sinus $0.2-1.0 \mathrm{~cm}$ long, slightly glaucous beneath, dark green above or dark green above with a deep violet interveinal zone and light green beneath, intramarginal veins several, petiole longer than the blade, $12-68 \mathrm{~cm}$ long, sheathing for almost half the length, green with purple, light and deep purple. Peduncle slender, $8-20 \mathrm{~cm}$ long, green with purple. Spathe erect, basal section 1.6-2.3 $\times 1.0-1.3 \mathrm{~cm}$, green, blade narrowly lanceolate, very finely acuminate, orange-yellow, $6.0-14.5 \mathrm{~cm}$ long, more thick. Spadix shorter than spathe, female zone 1.2-2.0 $\times 0.5-0.6 \mathrm{~cm}$ with 4-6 rows of whitish sterile ovaries at the base, no narrowed zone of neuters above, male zone 1.5-2.1 $\times 0.4-0.6 \mathrm{~cm}$, anthers oblong, slightly compressed with the flat top crenulate, dehiscing by apical pores, appendix $3.5-5.7 \times 0.2-0.3 \mathrm{~cm}$, acute, scalyrough, with several rows of sterile male flowers at the base, c. $1.1 \mathrm{~cm}$ long, c. $0.3 \mathrm{~cm}$ in diameter. Ovaries sub-globose, c. $1.1 \mathrm{~mm}$ in diameter, 1-locular, ovules many, hemiorthotropous on the parietal placentation, green, style short, stigma disciform. Fruit many-seeded, ovoid to ellipsoid.

Flowering and fruiting period: April to September.

Chromosome number: $2 \mathrm{n}=30$ (Begum and Alam, 2009).

Ecology: Grows on the hill slopes as under growth.

Distribution: North-Eastern part of Bangladesh, Moulvibazar district (within greater Sylhet) and South-Eastern part of Bangladesh, Bandarban district.

Specimens examined: Bandarban: Betchari forest area, 22.09.2004, Hosne Ara HA 1188 (DACB); Thanchi, 24.09.2004, Hosne Ara HA 1358 (DACB); Moulvibazar: Madhabkundo reserve forest, 20.05.2005, Hosne Ara HA 1709 (DACB); ibid 06.07.2005, Hosne Ara HA 1844 (DACB); ibid 03.12.2014, Hosne Ara HA 2867 (DACB); Dhaka: Bangladesh National Herbarium garden (Cultivated), 20.06.2015, Hosne Ara HA 2883 (DACB) [Originally collected from Madhabkundo forest under Moulvibazar district].

Etymology: The variety is named after green with purple, light and deep purple colour character of its petiole and peduncle. 


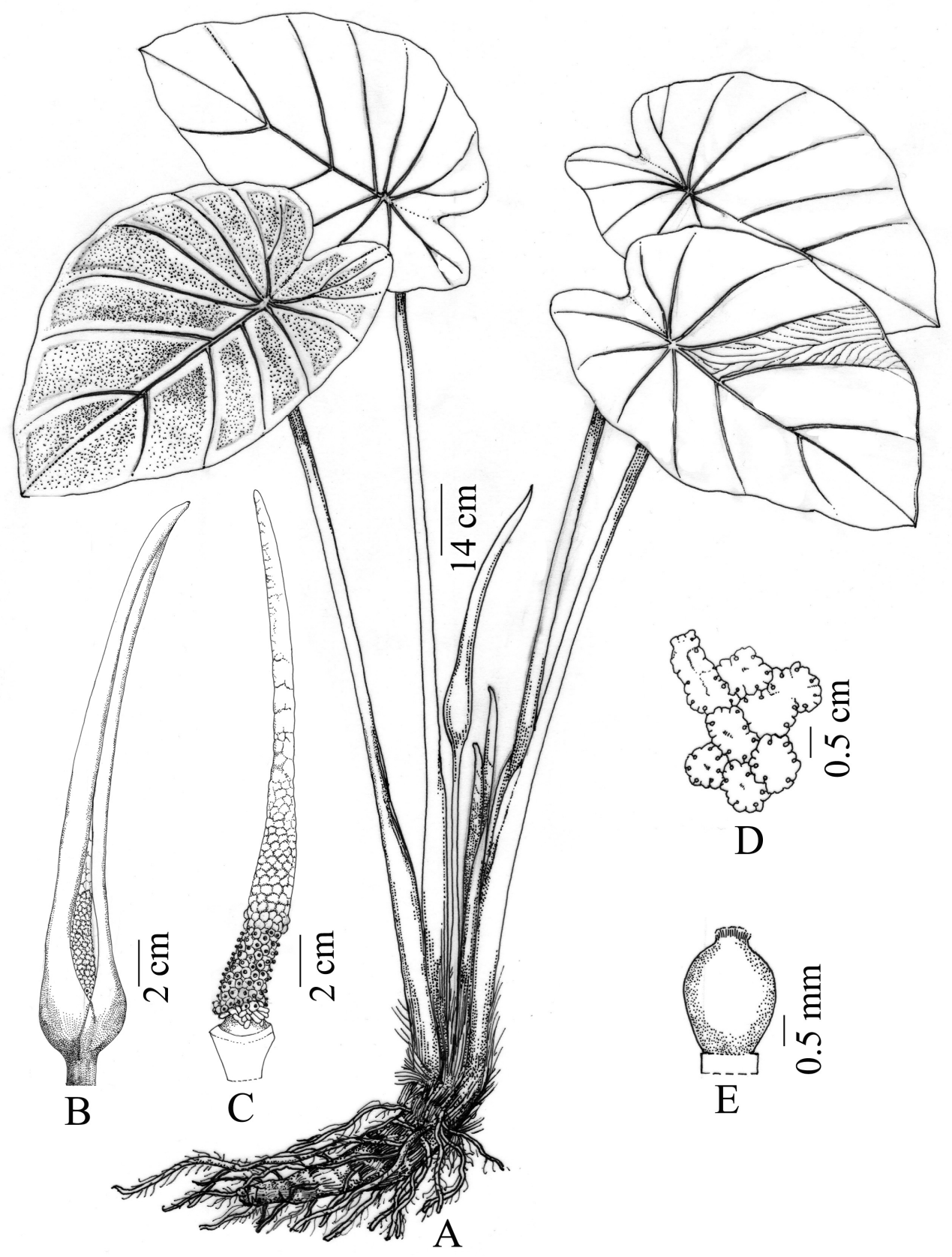

Fig. 1. Colocasia fallax Schott var. purpurea H. Ara \& M.A. Hassan, var. nov.: A. Habit; B. Inflorescence; C. Sapdix; D. Synandria (top view); E. Gynoecium. 

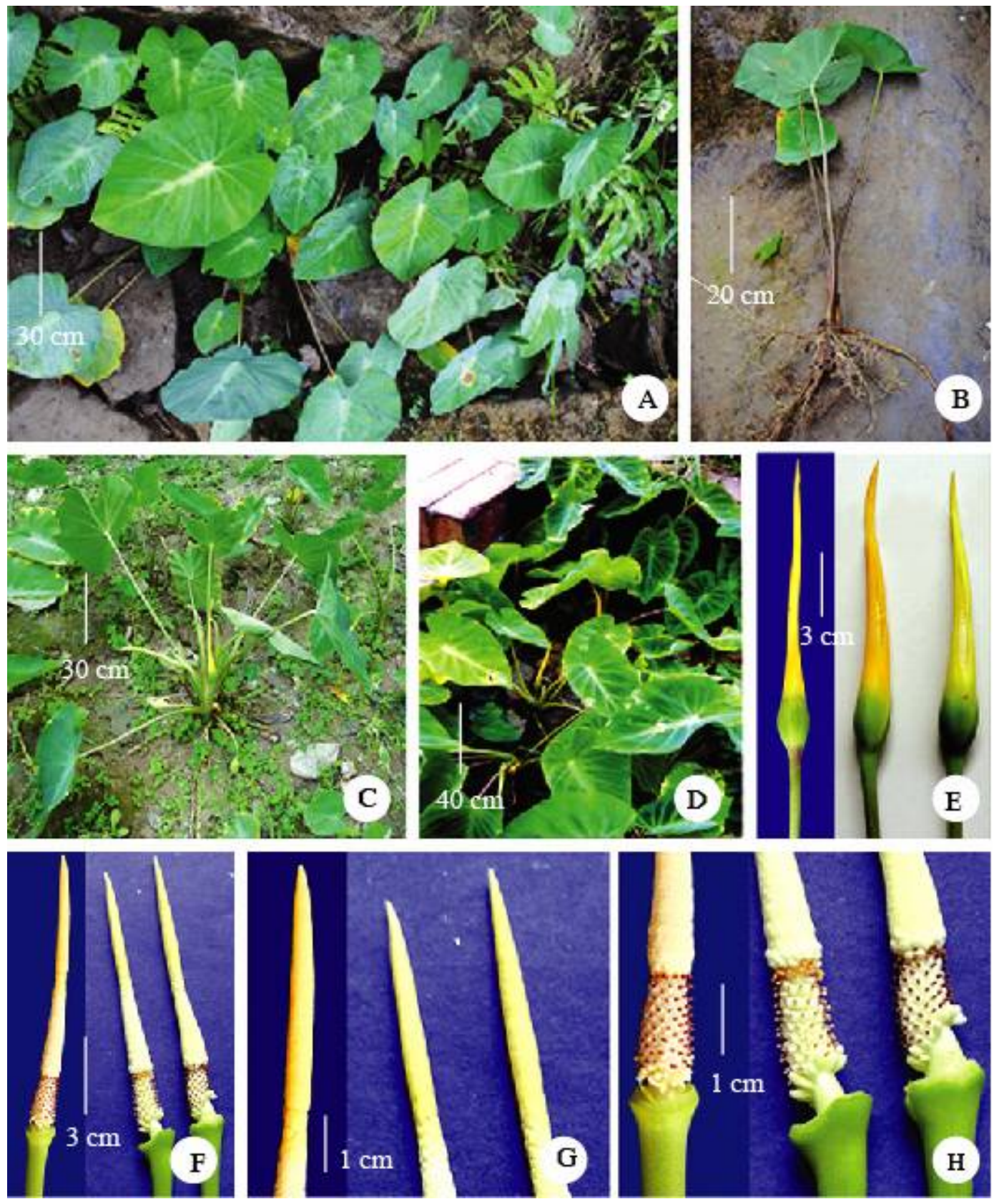

Fig. 2. Colocasia fallax Schott var. purpurea H. Ara \& M.A. Hassan, var. nov.: A, B. Wild habitat; C, D. Habit at BNH garden; E. Inflorescence; F. Spadix; G. Lower portion of the appendix; H. Lower portion of the spadix. 
The major morphological and cytological differences between two varieties of Colocasia fallax Schott are outlined in Table 1.

Table 1. Morphological and cytological comparison of Colocasia fallax Schott var. purpurea H. Ara \& M.A. Hassan, var. nov. and C. fallax Schott var. fallax.

\begin{tabular}{lll}
\hline Characters & $\begin{array}{l}\text { Colocasia fallax Schott var. purpurea } \\
\text { H. Ara \& M.A. Hassan, var. nov. }\end{array}$ & Colocasia fallax Schott var. fallax \\
\hline Petiole and peduncle & $\begin{array}{l}\text { Green with purple to light purple } \\
\text { admixture }\end{array}$ & Green throughout the length \\
Sterile male zone & Not less than $1.0 \mathrm{~cm}$ long & Not more than $0.6 \mathrm{~cm}$ long \\
Chromosome number & $2 \mathrm{n}=30$ & $2 \mathrm{n}=28$ (Begum and Alam, 2009) \\
Acrocentric chromosome & Present (one pair) & Absent \\
Small chromosome & Present (7 pairs) & Absent \\
CMA-Band & CMA-positive bands 2 & CMA-positive bands 8 \\
\hline
\end{tabular}

Conservation status: Collected only from three localities under two distant districts. With forest cleaning existence of this new variety may also become threatened and conservation status of this variety is VU (Vulnerable) (IUCN, 2017).

2. Colocasia oresbia A. Hay var. stolonifera H. Ara \& M.A. Hassan, var. nov. (Figs 3 \& 4).

Diagnosis: Colocasia oresbia A. Hay var. obtusifolia H. Ara \& M.A. Hassan differs from its closely related variety Colocasia oresbia A. Hay var. oresbia by its tuber character (up to $7.0 \mathrm{~cm}$ long and $4 \mathrm{~cm}$ in diameter); presence of white small stolon; leaf shape ovate-sagittate (up to $52 \mathrm{~cm}$ long and $36 \mathrm{~cm}$ in diameter); number of inflorescence in groups of up to 3 and male zone c. $5.5 \mathrm{~cm}$ long.

Holotype: Bangladesh, Rangamati district, Rangamati forest area, 27.09.2004, Hosne Ara HA 1435 (DACB).

Bengali name: Ban kachu.

Perennial herb, tuber c. $4.5-7.0 \mathrm{~cm}$ long and c. $1.8-4.0 \mathrm{~cm}$ in diameter, stolon small, white. Leaves thin, petiole c. $99.5 \mathrm{~cm}$ long, light green, sheathing for about $1 / 3$ at the base; blade peltate, $45-52 \times 32-36 \mathrm{~cm}$, ovate-sagittate, acute, base cordate, light green above and beneath, primary lateral veins 5-6 pairs, venation pinnately reticulate, pale green, sinus c. $8.0 \mathrm{~cm}$ long. Inflorescence solitary or paired, peduncle $30-35 \mathrm{~cm}$ long, c. $0.7 \mathrm{~cm}$ in diameter, light green, shorter than the petiole. Spathe constricted, $19.5-25.0 \mathrm{~cm}$ long, tube light green, $2.3-3.5 \mathrm{~cm} \mathrm{long}$, c. $2.5 \mathrm{~cm}$ in diameter, upper part reflexed, golden yellow, 17.0-21.5 cm long, 5-6 cm in diameter at the middle. Spadix sessile, shorter than the spathe, $11.5-13.5 \mathrm{~cm}$ long, female zone cylindrical, $2.1-3.0 \mathrm{~cm}$ long, $0.8-1.0 \mathrm{~cm}$ in diameter, sterile portion $1.0-1.5 \mathrm{~cm}$ long, cream, c. $0.5 \mathrm{~cm}$ in diameter at the middle, male portion $4.7-5.5 \mathrm{~cm}$ long, $0.5-0.6 \mathrm{~cm}$ in diameter, light yellow, appendix $3.0-3.5 \mathrm{~cm}$ long, c. $0.4 \mathrm{~cm}$ in diameter at the middle, light yellow, tip of the appendix blunt. Male flower 6-8 androus. Ovaries numerous, narrow, green, $1.5-2.0 \mathrm{~mm}$ long, $2-3 \mathrm{~mm}$ in diameter, style very short, green, stigma c. $0.05 \mathrm{~cm}$ in diameter, yellow. Ovule numerous. Staminode cream colour, $0.2-0.3 \mathrm{~cm}$ long, c. $0.15 \mathrm{~cm}$ in diameter.

Flowering and fruiting period: August to October.

Ecology: Grows on the hill slopes as under growth. 
Distribution: South-Eastern part of Bangladesh, Rangamati district.

Specimens examined: Rangamati: Rangamati forest area, 27.09.2004, Hosne Ara HA 1435 (DACB); Dhaka: Bangladesh National Herbarium garden (Cultivated), 10.08.2015, Hosne Ara HA 2894 (DACB); 13.09.2015, Hosne Ara HA 2895 (DACB); 17.09.2015, Hosne Ara HA 2896 (DACB) [Originally collected from Rangamati forest area under Rangamati district].

Etymology: The variety is named after the presence of white small stolon.

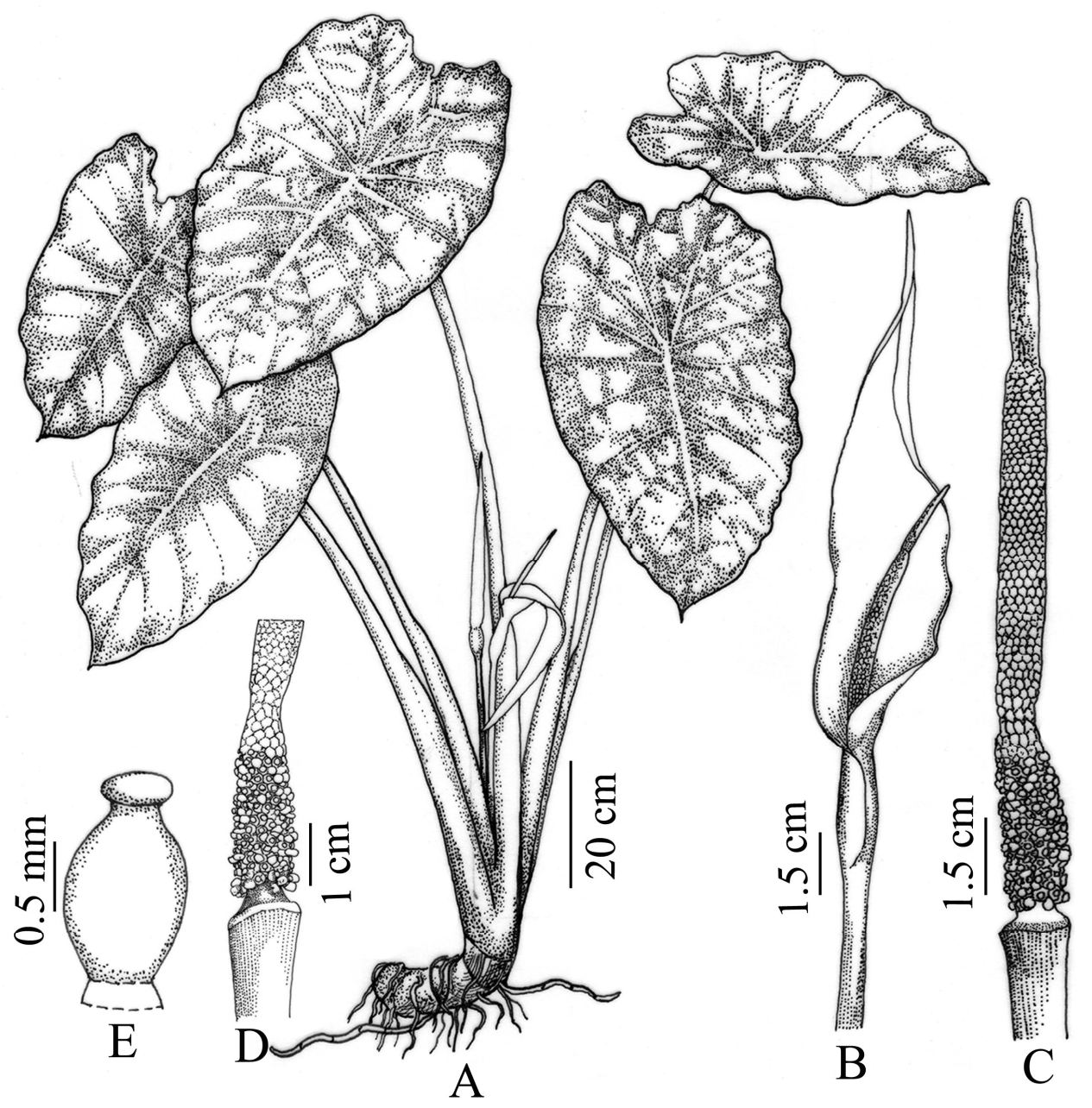

Fig. 3. Colocasia oresbia A. Hay var. stolonifera H. Ara \& M.A. Hassan, var. nov.: A. Habit; B. Inflorescence; C. Spadix; D. Lower portion of the spadix; E. Gynoecium.

Note: The chromosome number has been determined for the new variety Colocasia oresbia A. Hay var. stolonifera. Preliminary determination of $2 \mathrm{n}$ chromosome number appears as 26 . 

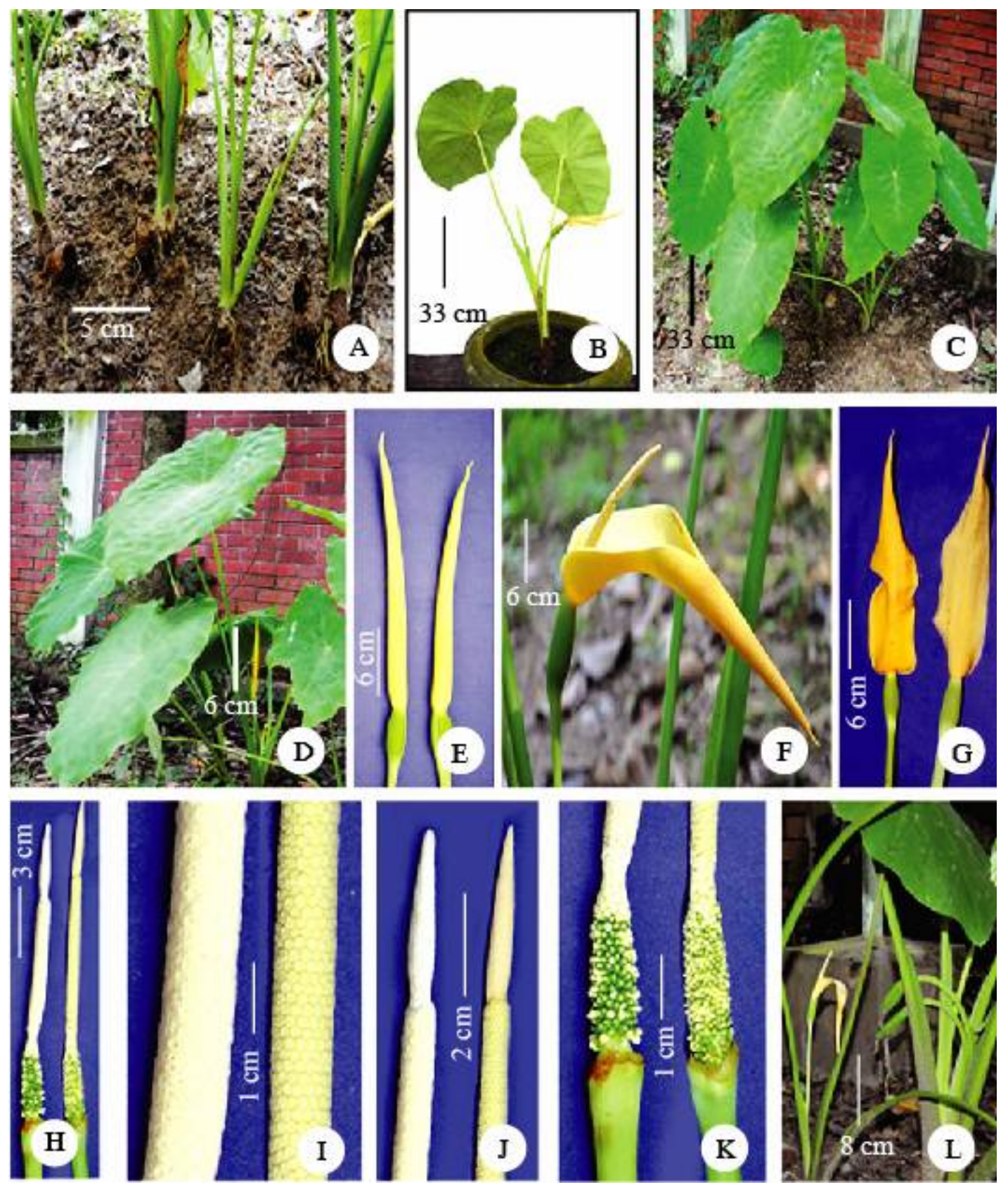

Fig. 4. Colocasia oresbia A. Hay var. stolonifera H. Ara \& M.A. Hassan, var. nov.: A. Tuber; B. Habit - at home garden; C. Habit at BNH garden; D, E, F. Inflorescence; G. Outside of the spathe; H. Spadix; I. Male zone; J. Appendix; K. Lower portion of the spadix; L. Fruiting peduncle. 
The major morphological differences between two taxa of Colocasia oresbia A. Hay are outlined in Table 2.

Table 2. Morphological comparison of Colocasia oresbia A. Hay var. stolonifera H. Ara \& M.A. Hassan, var. nov. and C. oresbia A. Hay var. oresbia.

\begin{tabular}{|c|c|c|}
\hline Characters & $\begin{array}{l}\text { Colocasia oresbia A. Hay var. stolonifera } \mathrm{H} \text {. } \\
\text { Ara \& M.A. Hassan, var. nov. }\end{array}$ & Colocasia oresbia A. Hay var. oresbia \\
\hline Tuber & $\begin{array}{l}\text { Up to } 7.0 \mathrm{~cm} \text { long and } 4 \mathrm{~cm} \text { in diameter } \\
(4.5-7.0 \times 1.8-4.0)\end{array}$ & $\begin{array}{l}\text { Not less than } 20 \mathrm{~cm} \text { long and } 8 \mathrm{~cm} \text { in } \\
\text { diameter }(25-40 \times 8-12)\end{array}$ \\
\hline Stolon & Present & Absent \\
\hline $\begin{array}{l}\text { Leaf shape \& } \\
\text { texture }\end{array}$ & $\begin{array}{l}\text { Apex and posterior lobe obtuse, leaf blades } \\
\text { shallowly peltate, } 45-52 \times 32-36 \mathrm{~cm} \text {, ovate- } \\
\text { sagittate }\end{array}$ & $\begin{array}{l}\text { Apex and posterior lobe semicircular, } \\
\text { leaf blades deeply peltate, } 60-84 \times 50- \\
65 \mathrm{~cm} \text {, very broadly ovate-sagittate }\end{array}$ \\
\hline Inflorescence & In groups of up to 3 & In groups of up to 8 , never 3 or less \\
\hline
\end{tabular}

Conservation status: This new variety is based on only one collection from Rangamati district, although further collections were made from DACB campus where it was cultivated. Status EN (Endangered) (IUCN, 2017).

\section{Rhaphidophora calophyllum Schott var. violaceus H. Ara \& M.A. Hassan, var. nov.}

(Figs 5 \& 6).

Diagnosis: Rhaphidophora calophyllum Schott var. violaceus H. Ara \& M.A. Hassan differs from its closely related Rhaphidophora calophyllum Schott var. calophyllum by the length of petiole $(3.5-6.0 \mathrm{~cm})$ and peduncle $(8.5-20 \mathrm{~cm}$ long); length and colour of the spathe blade that is $5.5 \mathrm{~cm}$ long and the colour is dark violet (outside) and light creamy pinkish (inside) and length of the spadix is $3.5-4.0 \mathrm{~cm}$.

Holotype: Bangladesh, Moulvibazar district, Madhabkundo reserve forest, 20.05.2014, Sarder Nasir Uddin N 5242 (DACB).

A perennial evergreen climber, rooting on trees, stem 5-6 mm thick. Leaves many, petiolate, entire, petiole $3.5-6.0 \mathrm{~cm}$ long, channelled up to the base, blade $11-23 \times 3.5-5.0 \mathrm{~cm}$ with $1-2 \mathrm{~cm}$ long acumen, coriaceous, falcately lanceolate or lanceolate, abruptly acuminate, both side rounded or cuneate at base, brownish-green on drying, nerves with anastomosing nervules and usually all similar, rarely 3-5 primary nerves more prominent towards the base. Inflorescence solitary. Peduncle short, $1.5 \mathrm{~cm}$ long, round, smooth, light greenish. Spathes thickly coriaceous, ovate, dark violet outside, light creamy pinkish within, $5.5 \times 2.5 \mathrm{~cm}$, long-beaked, tip of the beak light greenish. Spadix shorter than spathe, narrower, $3.5-4.0 \mathrm{~cm}$ long, light yellowish. Flowers bisexual. Stamens 4, free, anthers linear, much shorter than filament, filament flat, free at the apex, dehiscing by longitudinal slit. Ovary smooth, creamy, c. $3.5 \mathrm{~mm}$ long, c. $1.8 \mathrm{~mm}$ in diameter, unilocular, ovules many, anatropous, placentation parietal, stigma raised on the conical top of the ovary. Fruit not seen.

Flowering and fruiting period: April-September.

Ecology: Subtropical and tropical rain forests.

Distribution: North-Eastern part of Bangladesh, Moulvibazar district (within greater Sylhet). 
Specimen examined: Moulvibazar: Adampur forest beat, Kamalganj, 19.05.2014, Sarder Nasir Uddin N 5172 (DACB); Madhabkundo reserve forest, 20.05.2014, Sarder Nasir Uddin N 5242 (DACB).

Etymology: The variety is named after violet colour of its spathe.

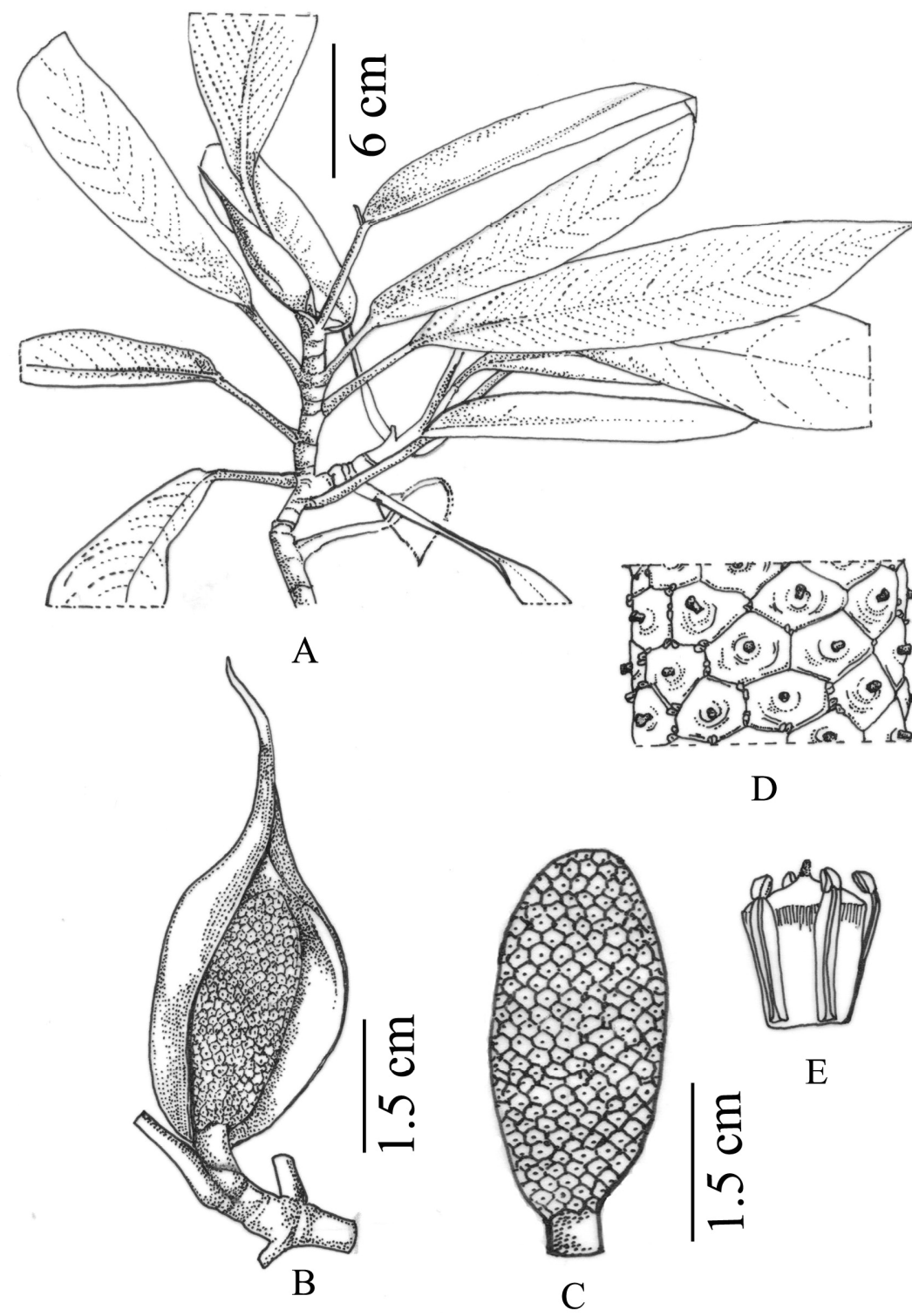

Fig. 5. Rhaphidophora calophyllum Schott var. violaceus H. Ara \& M.A. Hassan, var. nov.: A. Habit; B. Inflorescence; C. Spadix; D. Detail of spadix; E. Flower. 

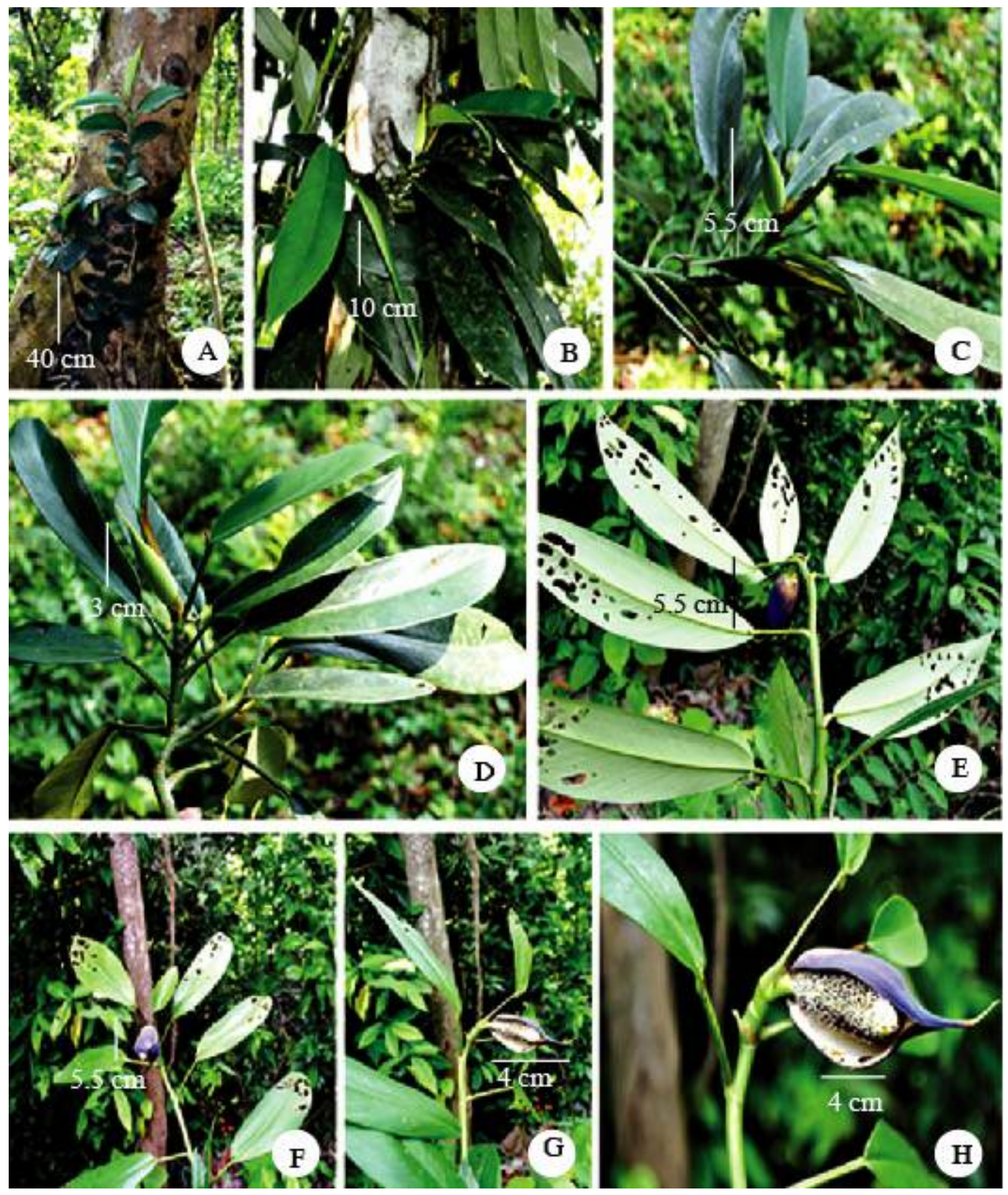

Fig. 6. Rhaphidophora calophyllum Schott var. violaceus H. Ara \& M.A. Hassan, var. nov.: A. Wild habitat; B. Blade; C, D. Inflorescence; E, F. Outside of the spathe; G, H. Inside of the spathe and spadix. 
The major morphological differences between two varieties of Rhaphidophora Hasskarl. are outlined in Table 3.

Table 3. Morphological comparison of Rhaphidophora calophyllum Schott var. violaceus H. Ara \& M.A. Hassan, var. nov. and $\boldsymbol{R}$. calophyllum Schott var. calophyllum

\begin{tabular}{lll}
\hline Characters & $\begin{array}{l}\text { Rhaphidophora calophyllum Schott var. } \\
\text { violaceus } \text { H. Ara \& M.A. Hassan, var. nov. }\end{array}$ & $\begin{array}{l}\text { Rhaphidophora calophyllum } \text { Schott } \\
\text { var. calophyllum }\end{array}$ \\
\hline Petiole & Short, $3.5-6.0 \mathrm{~cm}$ & Long, 8.5-20.0 cm \\
Peduncle & Short, up to $1.5 \mathrm{~cm}$ & Long, $3-5 \mathrm{~cm}$ \\
Spathe blade & Short, up to $5.5 \mathrm{~cm}$ & Long, $8-11 \mathrm{~cm}$ \\
Spathe colour & $\begin{array}{l}\text { Dark violet outer side and creamy pinkish inner } \\
\text { side }\end{array}$ & $\begin{array}{l}\text { Orange outer side and pale or dark red } \\
\text { inner side }\end{array}$ \\
\hline
\end{tabular}

Conservation status: Collected only from Moulvibazar district of Bangladesh, and the new variety is based on only two collections. It's existence also depends on the supporting trees. Status EN (Endangered) (IUCN, 2017).

4. Typhonium trilobatum (L.) Schott var. fulvus H. Ara \& M.A. Hassan, var. nov. (Figs 7 \& 8). Diagnosis: Typhonium trilobatum (L.) Schott var. fulvus H. Ara \& M.A. Hassan differs from its closely related variety Typhonium trilobatum (L.) Schott var. trilobatum by the twisted tip of the spathe, pale purple appendix, that is very shortly stipitate with crenulate or multifurcate base and light yellowish creamy stigma.

Holotype: Bangladesh, Netrakona district, Farangpara, 18.06.2004, Hosne Ara HA 865 (DACB).

Bengali name: Ban kachu.

Perennial herb, tuber c. $5 \mathrm{~cm}$ long, c. $4 \mathrm{~cm}$ in diameter. Petiole $15-55 \mathrm{~cm}$ long, c. $0.8 \mathrm{~cm}$ in diameter, green. Leaf paired, blade usually deeply trilobed, anterior lobe ovate-lanceolate, to c. $18.0 \mathrm{~cm}$ long, c. $9.5 \mathrm{~cm}$ in diameter, posterior lobe c. $18 \mathrm{~cm}$ long, c. $8 \mathrm{~cm}$ in diameter, green. Inflorescence paired. Peduncle c. $4 \mathrm{~cm}$ long, c. $1 \mathrm{~cm}$ diameter, green. Spathe c. $17 \mathrm{~cm} \mathrm{long,} \mathrm{tube}$ and blade separated by a strong constriction; tube c. $3 \mathrm{~cm}$ long, outside green, inside light green; blade c. $14 \mathrm{~cm}$ long, c. $8 \mathrm{~cm}$ in diameter at the middle, outside dark green, inside light purple, tip of the spathe twisted up to $4 \mathrm{~cm}$. Spadix shorter than spathe, c. $11 \mathrm{~cm}$ long; female zone c. $1 \mathrm{~cm}$ long, c. $1 \mathrm{~cm}$ in diameter, flowers congested; sterile zone between female and male zone 2.3-2.5 $\mathrm{cm}$ long, the lower $0.8-1.0 \mathrm{~cm}$ densely covered with staminodes, the remainder naked, cream colour, longitudinally grooved; male zone cylindrical, c. $1.6 \mathrm{~cm}$ long, c. $1.0 \mathrm{~cm}$ in diameter; base and top oblique, flowers congested; appendix very shortly stipitate, stipe c. $1 \mathrm{~mm}$ long, elongate conical, c. $6.5 \mathrm{~cm}$ long, c. $1.3 \mathrm{~cm}$ in diameter at the base, pale purple, top acute, base crenulate or multifurcate, producing a strong unpleasant smell at female anthesis. Ovaries cylindrical, c. $1 \mathrm{~mm}$ long, c. $1 \mathrm{~mm}$ in diameter, yellowish green, unilocular, with one basal ovule; stigma sessile, large, discoid, with a central depression, $0.8 \mathrm{~mm}$ in diameter, $0.2 \mathrm{~mm}$ long, densely shortly papillose, light yellowish cream. Staminode filiform, c. $1.5 \mathrm{~cm}$ long, c $0.3 \mathrm{~mm}$ in diameter, creamy white or light yellowish, curled.

Flowering and fruiting period: April-November.

Chromosome number: $2 \mathrm{n}=18$ (Warasy and Alam, 2009). 
Ecology: Shady moist areas.

Distribution: Northern part of Bangladesh.

Specimens examined: Netrakona: Durgapur, Farangpara, 18.06.2004, Hosne Ara HA 865 (DACB); Dhaka: Khilgaon, Tilpapara (Cultivated), 30.05.2006, Hosne Ara HA 2648 (DACB); ibid 22.09.2015, Hosne Ara HA 2902 (DACB) (Originally collected from Farangpara under Netrakona district).

Economic uses/values/harmful aspects: Young leaf and petiole of this plant are used as a vegetable.

Etymology: The variety is named after light yellowish cream colour of its stigma.

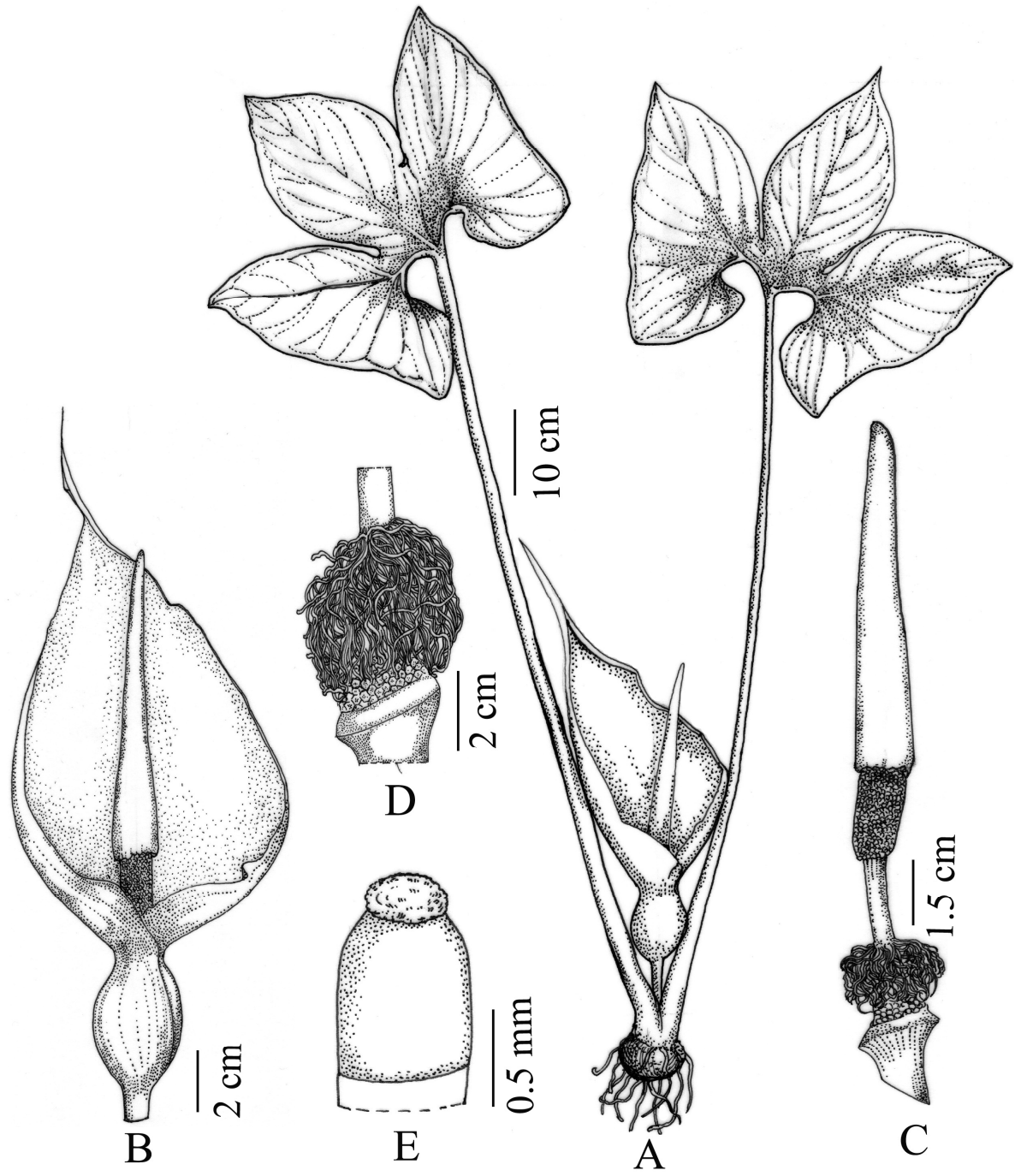

Fig. 7. Typhonium trilobatum (L.) Schott var. fulvus H. Ara \& M.A. Hassan, var. nov.: A. Habit; B. Inflorescence; C. Spadix; D. Lower portion of the spadix; E. Gynoecium. 

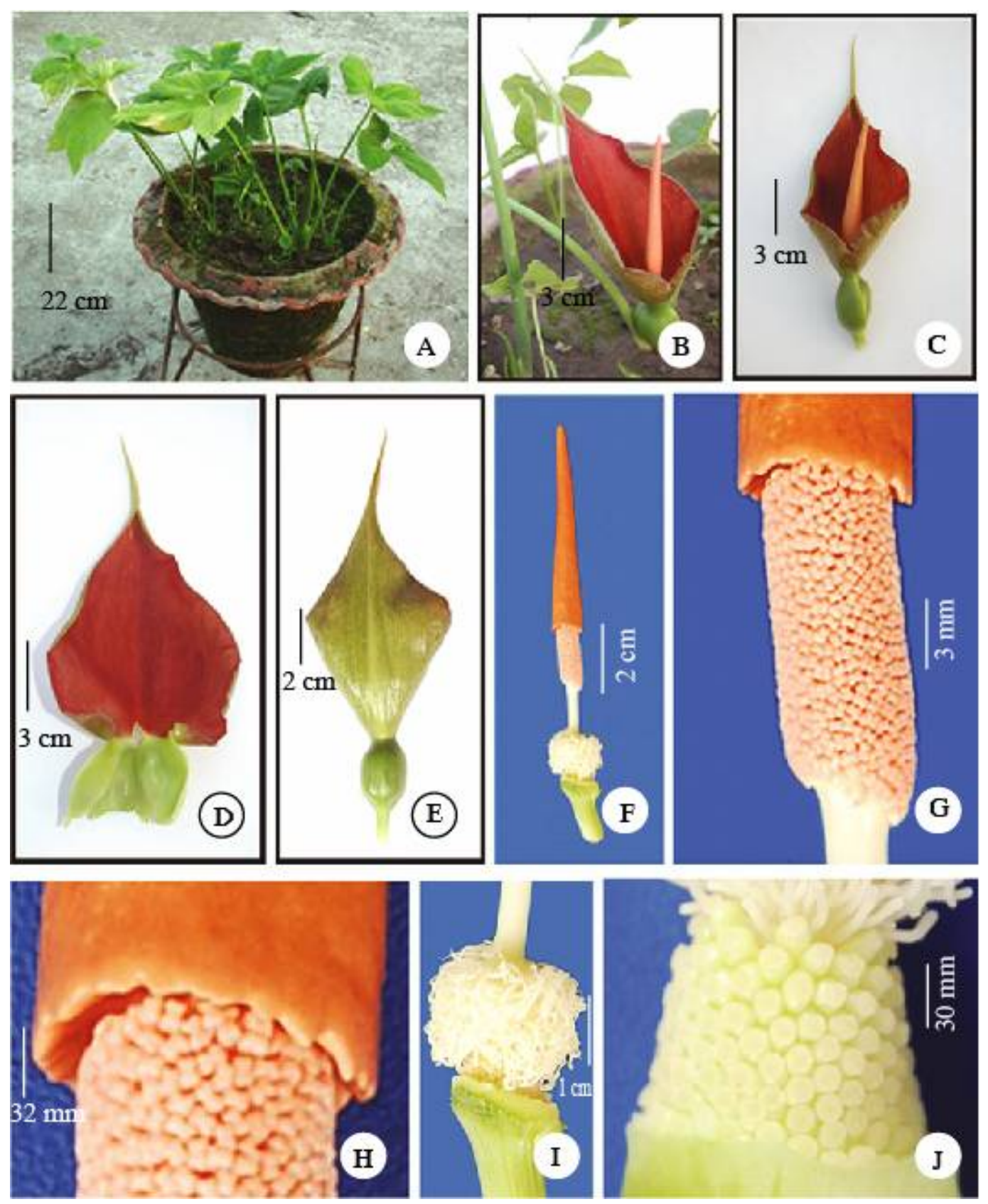

Fig. 8. Typhonium trilobatum (L.) Schott var. fulvus H. Ara \& M.A. Hassan, var. nov.: A. Habit at home garden; B, C. Inflorescence; D. Inside of the spathe; E. Outside of the spathe; F. Spadix; G. Male zone; H. Male zone and lower portion of the appendix; I. staminodes; J. Lower portion of the spadix. 
The major morphological and cytological differences between two taxa of Typhonium trilobatum (L.) Schott are outlined in Table 4.

Table 4. Morphological and cytological comparison of Typhonium trilobatum (L.) Schott var. fulvus $\mathbf{H}$. Ara \& M.A. Hassan, var. nov. and Typhonium trilobatum (L.) Schott var. trilobatum.

\begin{tabular}{lll}
\hline Characters & $\begin{array}{l}\text { Typhonium trilobatum (L.) Schott var. } \\
\text { fulvus } \text { H. Ara \& M.A. Hassan, var. nov. }\end{array}$ & $\begin{array}{l}\text { Typhonium trilobatum }(\mathrm{L} .) \\
\text { Schott var. trilobatum }\end{array}$ \\
\hline Tip of the spathe & Twisted, up to $4 \mathrm{~cm}$ & Not twisted \\
Appendix & $\begin{array}{l}\text { Pale purple, stipe c. 1 mm long, base } \\
\text { crenulate or multifurcate }\end{array}$ & $\begin{array}{l}\text { Glossy purple or reddish, stipe } \\
\text { 2-3 mm long, base truncate }\end{array}$ \\
Sterile zone & Densely covered with staminode & Loosely covered with staminode \\
Stigma colour & Light yellowish cream & Purple \\
Chromosome number & $18(16 \mathrm{~m}+2 \mathrm{ac})$ & $18(16 \mathrm{~m}+2 \mathrm{sm})$ \\
& & (Warasy and Alam, 2009) \\
Acrocentric chromosome & Present & Absent \\
CMA & CMA-band absent & CMA-band present \\
\hline
\end{tabular}

$\mathrm{m}=$ metacentric chromosome, $\mathrm{sm}=$ submetacentric chromosome, $\mathrm{ac}=$ acrocentric chromosome.

Conservation status: The new variety is located in a single locality in the wild and therefore, the status of this new variety is EN (Endangered) (IUCN, 2017).

\section{Acknowledgements}

The author is grateful to the authorities of the BK, BKF, BM, CAL, DACB, K, DUSH, HCU, BCSIRH and BFRIH for providing facilities to consult aroid materials and their libraries. The authors express their gratitude to Professor Dr. M. Oliur Rahman and Professor Dr. Mohammed Almujaddade Alfasane, Department of Botany, University of Dhaka for their encouragement and help during the final preparation of the manuscript. Thanks are also due to Ms. Mahmuda Akter, Senior Artist-cum-illustrator, Bangladesh National Herbarium for drawing the illustrations, and the researchers at Cytogenetics Laboratory of the Department of Botany, University of Dhaka for their cooperation in chromosomal investigation of the new varieties.

\section{References}

Ara, H. 2016. Taxonomic studies in the family Araceae from Bangladesh. Ph. D. Thesis (unpublished), Department of Botany, University of Dhaka, Bangladesh, pp. 1-524.

Begum, K.N. and Alam, S.S. 2009. Karyotype Analysis in Three Morphological Forms of Colocasia fallax Schott. Cytologia 74(2): 209-214.

Boyce, P.C. and Croat, T.B. 2011 (onwards). The Überlist of Araceae, Totals for published and estimated number of species in Aroid Genera. http://www.aroid.org/genera/ 180211 uberlist.pdf. (Accessed 05 November 2018).

Engler, A. 1920. Araceae-Aroideae, Araceae-Pistioideae. In: Engler, A. (Ed.), Das Pflanzenreich 73 (IV.23F): 1-274.

Engler, A. and Krause, K. 1908. Araceae-Monsteroideae. In: Engler, A. (Ed.), Das Pflanzenreich 37(IV.23B): 4-139. 
Engler, A. and Krause, K. 1920. Additamentum ad Araceas-Philodendroideas, Araceae-Colocasioideae. In: Engler, A. (Ed.), Das Pflanzenreich 71(IV.23E): 3-132.

Hay, A. 1993. The genus Typhonium (Araceae-Areae) in Australasia. Blumea 37(2): 345-376.

Hay, A. 1996. A new Bornean species of Colocasia Schott (Araceae: Colocasieae) with a synopsis of the genus in Malesia and Australia. Sandakania 7: 31-48.

Heinig, R.L. 1925. List of Plants of the Chittagong Collectorate and Hill Tracts. The Bengal Government Branch Press, Darjeeling, India, pp. 74-75.

Heng, Li, Guanghua Z., Boyce, P.C., Murata, J., Hetterscheid, W.L.A., Bogner, J. and Jacobsen, N. 2010. Araceae. In: Wu, Z.Y., Raven, P.H. and Hong, D.Y. (Eds.). Flora of China, Vol. 23 (Acoraceae through Cyperaceae). Science Press, Beijing, and Missouri Botanical Garden Press, St. Louis. pp. 3-79.

Hetterscheid, W.L.A. and Boyce, P.C. 2000. A reclassification of Sauromatum Schott and new species of Typhonium Schott (Araceae). Aroideana 23: 48-55.

Hooker, J.D. 1893 (Reprint 1954). The Flora of British India, Vol. 6. L. Reeve \& Co. Ltd., Kent, England, pp. 490-555.

Hu, S.Y. 1968. Araceae. Studies in the Flora of Thailand, no. 41. Dansk Bot. Arkiv 23(4): 409-457.

IUCN 2017. IUCN Standards and Petitions Subcommittee Guidelines for Using the IUCN Red List Categories and Criteria. Version 13. Prepared by the Standards and Petitions Subcommittee. Downloaded from http://www.iucnredlist.org/documents/RedListGuidelines.pdf. pp. 1-108.

Jackson, B.D. 1893-1955. Index Kewensis (An Eumeration of the Genera and Species of Flowering Plants. Vols. 1 \& 2. Oxford at the Clardon press, M DCCCXCV.

Karthikeyan, S., Jain, S.K., Nayar, M.P. and Sanjappa, M. 1989. Florae Indicae Enumeratio: Monocotyledonae. Flora of India Series 4. Araceae. Botanical Survey of India, Calcutta, pp. 5-15.

Liu, T.S. and Huang, T.C. 1996. Araceae. Flora of Taiwan, pp. 796-815.

Mayo, S.J. 1985. Araceae. In: Polhill, R.M. (Ed.), Flora of Tropical East Africa. Balkema, Rotterdam, the Netherlands, pp.1-71.

Mayo, S.J., Bogner, J. and Boyce, P.C. 1997. The Genera of Araceae. Royal Botanic Gardens, Kew, UK, pp. 1-370.

Nasir, Y.J. 1978. Araceae. In: Nasir, E. and Ali, S.I. (Eds), Flora of West Pakistan, No. 120. Agricultural Research Council, Islamabad, Pakistan, pp.1-17.

Nicolson, D.H. 1976 (Reprint 1978). Araceae. In: Saldanha, C.J. and Nicolson, D.H. (Eds). Flora of Hassan District, Karnataka, India. Amerind Publishing Co. Pvt. Ltd., New Delhi, Bombay, Calcutta and New York, pp. 781-790.

Nicolson, D.H. 1979. Araceae. In: Smith, A.C. (Ed.), Flora Vitiensis Nova, Vol. 1. Pacific Tropical Botanical Garden, Hawaii, pp. 438-460.

Nicolson, D.H. 1987. Araceae. In: Dassanayake, M.D. (Ed.), A Revised Handbook to the Flora of Ceylon, Vol. 6. Balkema, Rotterdam, the Netherlands, pp. 17-101.

Nicolson, D.H. and Sivadasan, M. 1981. Four frequently confused species of Typhonium Schott (Araceae). Blumea 27(2): 483-497.

Noltie, H.J. 1994. Araceae. In: Grierson, J.D. and Long, D.G. (Eds), Flora of Bhutan, Vol. 3(1). Royal Botanic Garden, Inverleith Row, Edinburgh, UK, pp.121-158.

Prain, D. 1903. Bengal Plants, Vol. 2. Indian reprint (1963), Botanical survey of India, Calcutta, pp. 830-840.

Rao, A.S. and Verma, D.M. 1976. Materials towards a monocot flora of Assam-V. Bull. Bot. Surv. Ind. 18(1-4): 9-34.

Roxburgh, W. 1832. Tetrandia monogynia in Willium Carey's Flora Indica; or Descriptions of Indian Plants. Mission Press, Serampore, India, pp. 620-635.

Sookchaloem, D. 1995. Typhonium (Araceae) in Thailand. Thai For. Bull. (Bot.) 23: 18-39.

Sriboonma, D., Murata, J. and Iwatsuki, K. 1994. A revision of Typhonium (Araceae). J. Fac. Sci. Univ. Tokyo, Sect. III. 15: 255-313. 
Toha, A.M.M. 2000. Biodiversity of aroids in southeast Bangladesh. M. Phil Thesis (unpublished). Aberdeen University, Scotland, U.K.

Wallich, N. 1829-1849. A numerical list of dried specimens of plants in the East Indian Company's Museum. Generally cited Wall. Cat., ined.

Wang, Z.L., Li H. and Bian F.. 2002. Typhonium jinpingense, a new species from Yunan, China with the lowest diploid chromosome number in Araceae. Novon 12: 286-289.

Warasy, A.A. and Alam, S.S. 2009. Comparison of Orcein and CMA stained Karyotypes in three morphological forms of Typhonium trilobatum L. (Araceae). Cytologia 74(3): 311-316.

Wight, R. 1843-1845. Icones Plantarum Indiae Orientalis or Figures of Indian Plants, Vol. 3 (part 1). Messrs, Ostell, Lepage and Co., Calcutta. pp. 772-808.

(Manuscript received on 3 January, 2019; revised on 7 May, 2019) 